\title{
TRANSPORT
}

DOI - 10.32743/UniTech.2021.86.5.11806

\section{ROAD TRANSPORTATION ACCIDENTS WITH PARTICIPATION PEDESTRIANS}

\author{
Sarvar Imomnazarov \\ Teacher, \\ Namangam Engineering Construction Institute, \\ Uzbekistan, Namangan \\ E-mail: sarvar199108@gmail.com
}

Zokirxon Munavvarxonov

Teacher,

Namangam Engineering Construction Institute,

Uzbekistan, Namangan

E-mail: zokirxon-1@mail.ru

Shamsiddin Turg'unpo'latov

Student,

Namangam Engineering Construction Institute,

Uzbekistan, Namangan

Axrorbek No'monjonov

Student,

Namangam Engineering Construction Institute,

Uzbekistan, Namangan

\section{ДОРОЖНО-ТРАНСПОРТНЫЕ ПРОИСШЕСТВИЯ С УЧАСТИЕМ ПЕШЕХОДОВ}

\author{
Имомназаров Сарвар Ковилжанович \\ преподаватель, \\ Наманганский инженерно-строительный институт, \\ Республика Узбекистан, г. Наманган \\ Мунаввархонов Зокирхон Тохирхон угли \\ преподаватель, \\ Наманганский инженерно-строительный институт, \\ Республика Узбекистан, г. Наманган \\ Тургунпулатов Шамсиддин Тохиржон угли \\ студент, \\ Наманганский инженерно-строчтельный институт, \\ Республика Узбекистан г. Наманган \\ Нумонжснов Ахрорбек Хурсандбек угли \\ студент, \\ Наманганский инженерно-строительный институт, \\ Республика Узбекистан г. Наманган
}

\footnotetext{
ABSTRACT

This article deals with road traffic accidents (accidents) involving pedestrians. Causes of the accident. Cases of material liability of participants of road accidents are considered. As well as foreign experience in preventing accidents involving pedestrians.

АННОТАЦИЯ

В этой статье рассматриваются дорожно-транспортные происшествия (ДТП) с участием пешеходов. Причины аварии. Рассмотрены случаи материальной ответственности участников ДТП. А также зарубежный опыт предотвращения аварий с участием пешеходов.
} 
Keywords: Road accidents involving pedestrians, hitting pedestrians.

Ключевые слова: ДТП с участием пешеходов, наезд на пешеходов.

Introduction. It is no secret that most warriors allow themselves to break the rules in small ways. Despite the fact that every person has an excuse ready, do not forget: it is small violations that often lead to serious consequences. Any person, whether a driver, pedestrian or passenger, who has violated the Traffic Rules (hereinafter referred to as Traffic Rules) can be held liable. The procedure for bringing to justice most often begins with an inspector of the State Road Safety Inspectorate (hereinafter referred to as the Traffic Police), but, despite this, as a result of a road traffic accident (hereinafter referred to as an accident), in addition to the persons involved in the accident, another subject is included in the resolution of this situation, namely the insurance company $[6,7,4]$.

For example, the story that changed the life of a teenager began in November 2017 at an intersection near the governor of the city of Namangan. On an unregulated crossing, Akmal (the boy's name) was hit by a Lada Granta car. He was taken to the hospital, where doctors diagnosed a compound fracture of the lower leg. On the same evening, the driver offered the parents compensation of 4,200,000 Sums, but they refused it. After that, the case went to the court of first instance, which decided that the accident was the fault of the child. Allegedly, the motorist did not violate the rules, drove at a speed of up to $50 \mathrm{~km} / \mathrm{h}$ and could not pass a pedestrian. The boy's family protested the verdict, as a result of which the regional court found her right. In the new lawsuit, the family also demanded to recover from the driver half a million sums for moral suffering and 50 thousand material damage.

However, when Akmal was recovering, he received a letter from the insurance company demanding compensation for the repair of the headlights of the car that hit him.

Having considered a number of examples from court practice in cases related to road accidents, it can be concluded that on average in $10 \%$ of the studied cases as a result of an accident, the pedestrian is responsible, while in the remaining $90 \%$ the burden of responsibility lies with the driver of the vehicle. This is not surprising, because if you look at the statistics of road accidents for 2019 (Fig. 1), you can make sure that in most accidents on the roads, the perpetrators are the persons driving the vehicle.

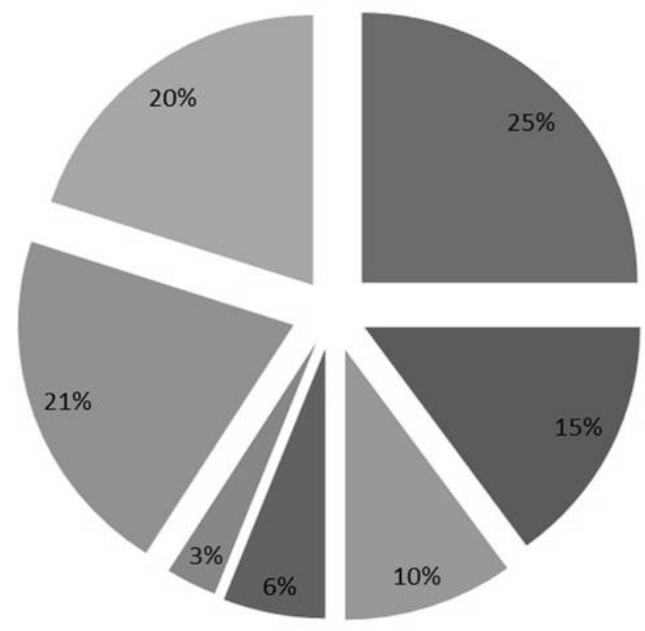

Non-compliance with the speed limit
$25 \%$
Violation of the rules of travel at the
intersection $15 \%$
Violation of traffic rules as a result of
alcohol intoxication of the driver $10 \%$
Exit to the oncoming lane $6 \%$
Violation of traffic rules by pedestrians
$3 \%$
Unsatisfactory condition of roads and
streets $21 \%$
Operation of faulty devices $20 \%$

Figure 1. Causes of road accidents in Uzbekistan in 2018

So, examining the data given in the diagram, we see that $59 \%$ of accidents, which is more than half, are caused by drivers, $21 \%$ of the responsibility lies on the shoulders of the Administration of a particular city due to the unsatisfactory condition of roads and streets $[4,8$, $1,9]$ and only $20 \%$ are guilty of pedestrians who violated traffic rules $[2,5,9]$. That is why payments for compensation for damage caused, most often have to be carried out by the drivers of the vehicle.

Since in the territory of the Republic of Uzbekistan there is legislation according to which "owners of vehicles are obliged, on the terms and in accordance with the procedure established by this Republican Law and in accordance with it, to insure the risk of their civil liability, which may occur as a result of causing harm to the life, health or property of other persons when using vehicles", a significant part of the payments for causing harm as a result of an accident is assigned to insurance companies, but as for the example I gave with George, then the insurance company demanded compensation for the repair of the headlights of the car that hit him. Interestingly, according to the law, the claims of insurers are legitimate, although they are quite rare. The whole point is that if the insurer compensates for the damage caused to the car during the collision, the company can demand payment of the costs from the person regardless of his guilt. Another thing is that the victim has the right to apply to the court with a demand to recover compensation 
for moral damage from the driver. The situation is certainly interesting. After all, if (as the court of first instance decided), the student is to blame, then his parents must pay for the damage caused to the car. In this case, the insurance company took advantage of, which states, " Unless otherwise provided by the property insurance contract, the insurer who paid the insurance indemnity shall, within the amount paid, have the right of claim that the policyholder (beneficiary) has against the person responsible for the losses compensated as a result of the insurance." However, the parents were absolutely right to file a counterclaim for compensation for non-pecuniary damage. Following the logic of the law, even if the damage was caused by intent, that is, the student deliberately ran across the road in front of an approaching car, he can still receive compensation. Yes, in this case it can be reduced, but not completely excluded. That is, it is likely that the driver himself will have to pay. It is on this example that you can make sure that everything fundamentally depends on whose fault the accident occurred.

If we turn to foreign experience and see how such situations are resolved there. For example, in Germany, as in Uzbekistan, video recorders or the so-called Dashcam are becoming increasingly popular. But according to German law, such a video is not material evidence, since it was not made by an expert. This is what hinders the process of proving who caused the accident. The recorded video may, at the discretion of the judge, perform only an auxiliary function.

Just as in Uzbekistan, it is not uncommon for pedestrians or cyclists to become victims of road accidents. There is a misconception that a pedestrian hit by a zebra is always right, no. A pedestrian is also a participant in the movement and should not insist on their priority right to cross. Not all drivers "respect" the zebra or simply do not always see it on the road, and then the transition ends with moving to the hospital ward. German courts require pedestrians to be particularly careful. Not only drivers, but also pedestrians were held liable for accidents (and reimbursed for car repairs). Despite the green light or the presence of a pedestrian crossing, the courts recognize up to $50 \%$ of the pedestrian's guilt. And when crossing in the wrong place, the fault can reach $100 \%$, because it is possible that the behavior of pedestrians is the cause of the accident. It is for this reason that German motorists need to be vigilant when participating in road traffic in order to remain healthy and maintain their financial situation, without paying for their treatment and repair of the vehicle as a result of a collision with which an accident occurred. It is this judicial practice that acts as a prevention of accidents with pedestrians. It should be noted that the prevention of road accidents in Uzbekistan is also a success. Over the 12 months of 2019, the trend of reducing the number of road accidents and the number of victims continued in the Republic of Uzbekistan. At the same time, the analysis of the structure and dynamics of accidents indicates the presence of problematic components of indicators of road traffic injuries. In particular, along with the reduction in accidents, certain components were identified, the values of which increased. Their analysis and accounting in the future will increase the effectiveness of preventive activities.

1. In the regions of the Republic of Uzbekistan, there was an increase in one, two or three main indicators of accidents, which had a negative impact on the process of improving road safety in the country. At the same time, the number of such subjects increased in comparison with 2019 (21 subjects).

2. Throughout the year (including for 3, 6, 9 months), the most dangerous day of the week in the country was Saturday, and the time of day was the period from 17:00 to 19:00 hours.

3. Among the total number of road accidents and the number of victims due to the fault of drivers of motor vehicles, accident rates due to traffic violations by bus and trolleybus drivers were particularly negative.

4. In 2020, there was an increase in accident rates due to traffic violations by drivers who are in a state of intoxication. In addition, there was a significant increase in the number of accidents due to traffic violations by drivers associated with oncoming traffic.

5. There was a deterioration in the situation related to the accident rate of vehicles belonging to legal entities. The increase in the number of accidents and the number of injured in them due to traffic violations by drivers of these vehicles was more than $11 \%$.

6. In the structure of accident rates due to traffic violations by drivers of different ages, the number of accidents and the number of injuries committed by drivers of the age group over 60 years continued to increase.

7. Accidents involving child passengers were of particular concern. The increase is due to an increase in the number of road accidents and the number of injured child passengers up to 12 years old.

In general, from 2011 to 2019 , the dynamics of the annual number of road accidents, the number of deaths and injuries had a pronounced downward trend, since their absolute values can be approximated by a straight downward trend line. In this regard, it is predicted that the values of accident rates will continue to decline, which is based on retrospective data for the years and timely determination of the current situation on the country's road network, including at the expense of new, modern cars [1, 3, 4]. Both versions of the forecast values provide for a favorable development of the situation, in particular, a decrease in the number of deaths relative to the values of 2019: based on the average annual decline in the period from 2008 to 2019 by more than $4.0 \%$ and more than $12.0 \%$ - based on the steady rate of decline in the last three years. Summing up the work done, it should be said that regardless of whether you are on a regulated pedestrian crossing or vice versa, you need to be $100 \%$ sure of your safety, especially if the pedestrian is a child [9] and only then start moving. If you are driving a vehicle, be careful and do not be distracted by third-party items, because one moment can cost someone their life. 


\section{List of literature:}

1. A. Normirzayev, A. Eshonbabayev, A. Polvonov, M. Ogalikov, G. To’xliyev Features of application of additional lanes on perevalny sites of roads in the mountain district "European Applied Sciences is an International, German/English” № 1 2015(January)

2. Vlasova E.P. improving the safety of pedestrian crossings /E.P. Vlasov, A.S. Ulrich, D.Y. Kashirskaya // Problems of the functioning of transport systems: materials of the International scientific and practical conference of students, postgraduates and young scientists: V 2 t. / OTV. edited by V.I. Bauer. - Tyumen, 2015. - S. 124 to 129.

3. Virada P. Yu. Introduction of intelligent transport systems / P. Yu. Vyroda, D. Yu. Kashirsky / / Organization and safety of road traffic: materials of the IX All-Russian scientific and practical conference. - Tyumen, 2016. - p. 96-99.

4. The construction of modern roads, as an element of road safety / P.U. Virada [et al.] / / Problems of the functioning of transport systems: materials of the International scientific-practical conference: in 2 volumes / Ed. edited by V.I. Bauer. - Tyumen, 2015. - P. 144-148.

5. Kapitonova K.Y. Questions on the safety of pedestrian crossings / K.S. Kapitonov, D.Y. Kashirskaya, S.A. Ulrich / Organization and traffic safety: proceedings of the VIII all-Russian scientific-practical conference. - Tyumen, 2015. - pp. 128-133.

6. Kashirskaya D.Y. features of the application of computer technology in the investigation of accidents / D.Y. Kashyrs'kyi, V.V. Polyakov // Organization and traffic safety: proceedings of X international scientific-practical conference dedicated to the 85th anniversary of the birth of doctor of technical Sciences, Professor L.G. Resnick: 2 T. Tyumen, 2017. - P. 288-294.

7. Kashirskaya D.Y. Determination of the culprit in a road traffic accident / D.Y. Kashirskaya, S.A. Ulrich // Actual problems of fight against crime and other offenses. -2015. - No. 13-1. - pp. 106-108.

8. Apalkova Ya.V. Improving road traffic safety through the use of robotic cars / Ya.V. Apalkova, D. Yu. Kashirsky, S.A. Ulrich / / Organization and safety of road traffic: materials of the IX All-Russian scientific and practical conference. - Tyumen, 2016. - p. 25-31.

9. https://www.lex.uz/acts/393177 